\title{
ALBERTO GUZIK
}
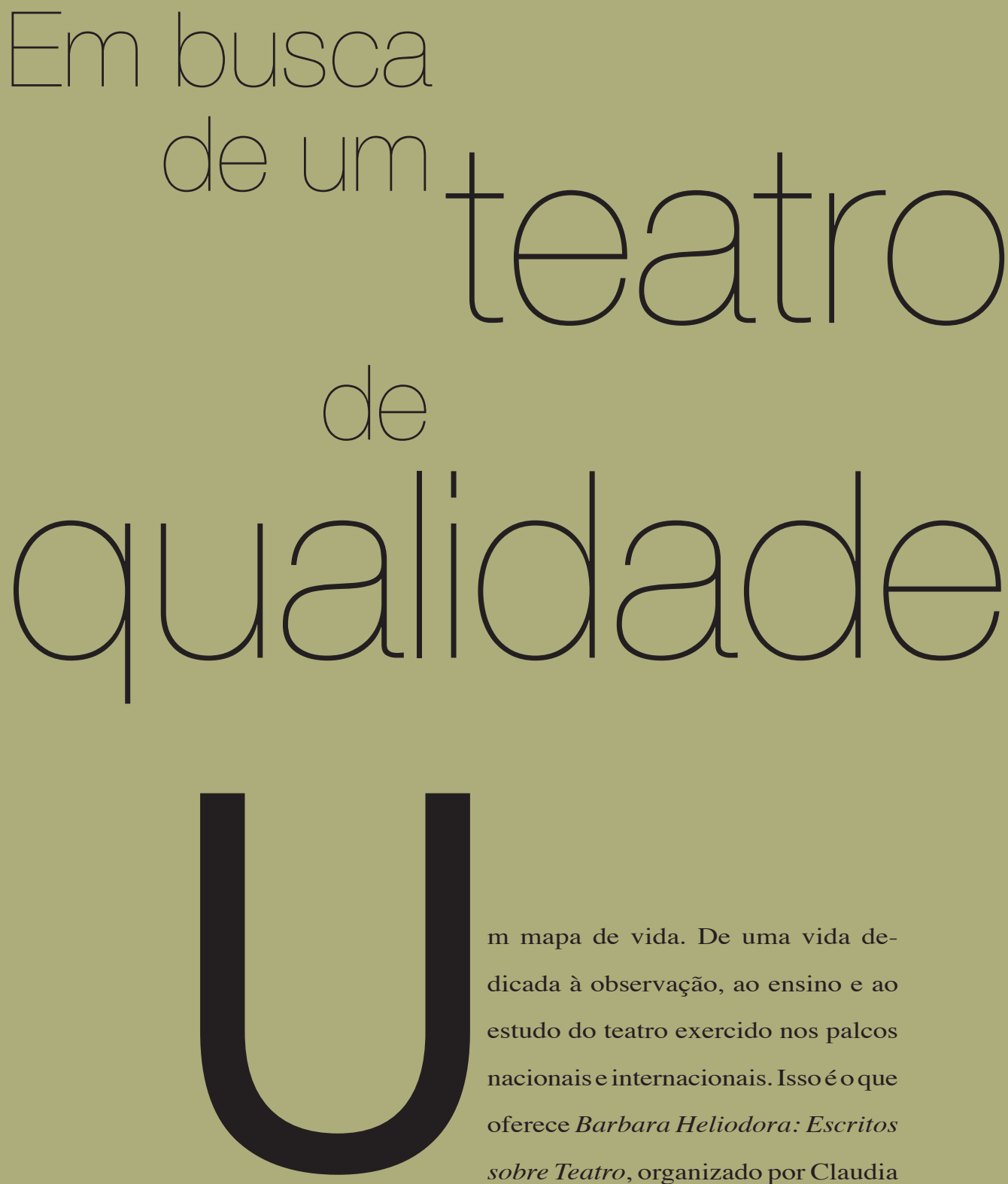

m mapa de vida. De uma vida dedicada à observação, ao ensino e ao estudo do teatro exercido nos palcos nacionais e internacionais. Isso é o que oferece Barbara Heliodora: Escritos sobre Teatro, organizado por Claudia

Braga e lançado no final de 2007 pela Editora Perspectiva de São Paulo, em sua coleção Textos. O mapa, nesse caso, é da vida da professora e pesquisadora carioca Heliodora Carneiro de Mendonça, mais conhecida pelo nom de plume Barbara Heliodora, uma das mais prestigiadas, temidas, polêmicas, acatadas e contestadas críticas teatrais do Brasil durante a segunda metade do século XX. Embora ela seja hoje a inconteste decana do ofício e continue engajada na crítica militante aos 84 anos, publicando seus comentários 


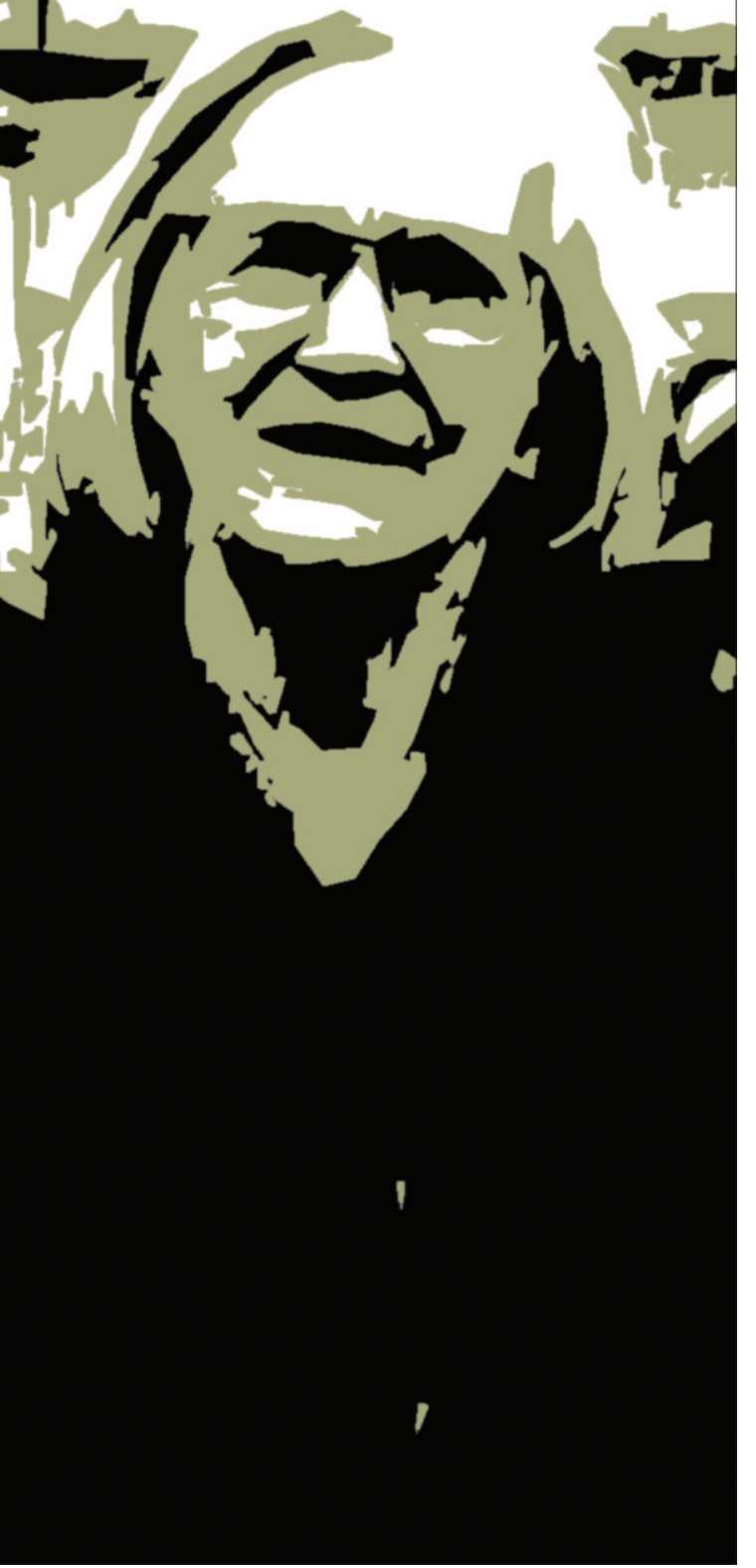

nas páginas do jornal carioca $O$ Globo, é razoável admitir que Escritos sobre Teatro enfeixa grande parte do corpus da produção de Barbara Heliodora destinada à imprensa. Estão incluídos nele trabalhos produzidos entre 1944 e 1994. A obra heliodoriana posteriorà segunda data ficou fora da massa de textos compilada por Claudia Braga. E de massa de textos se pode falar com toda a propriedade. O livro tem 950 páginas e pesa exatamente 1 quilo.

Não são suas dimensões prometéicas e sim seu conteúdo que interessa a este artigo. No entanto, é forçoso notar que o considerável lapso de tempo decorrido entre o primeiro e o último textos incluídos no livro permite ao leitor observar o trajeto da reflexão crítica empreendida pela autora. É possível, por meio desses Escritos sobre Teatro, analisar o percurso estético que Barbara Heliodora desbravou em cinco décadas. A obra foi dividida pela organizadora em quatro partes: "Pensando o Teatro", com textos teóricos produzidos entre 1944 e 1971, "Vida Teatral”, integrada por críticas escritas entre 1957 e 1969 , “Teatro e Estado", abarcando textos sobre política cultural e sobre as relações sempre conturbadas entre o teatro e o regime militar, produzidos de 1957 a 1970, e "No Palco e do Teatro", que traz críticas feitas de 1986 a 1994.

Apesar da enorme quantidade de artigos e críticas incluídos nos Escritos sobre Teatro, o livro não abarca a obra completa da autora no território jornalístico. A organizadora da obra fez sua seleção a partir da compilação dos escritos de Barbara Heliodora levantada e digitada por voluntários integrantes do Grupo de Estudos e Pesquisa em Teatro Brasileiro (Geteb), dirigido por Claudia Braga, que, em "À Guisa de Prefácio", informa que "Não foi, entretanto, tarefa das mais fáceis selecionar, entre as milhares de páginas resultantes da digitação dos textos escritos por esta prolífica crítica, aqueles que constariam desta coletânea" (p. 16). O que se pode expressar desde logoéa necessidade-dada a indiscutível relevância da produção de Barbara Heliodora e o fato de todo esse material se encontrar já digitado - de que seja incluído em um site, para que fique

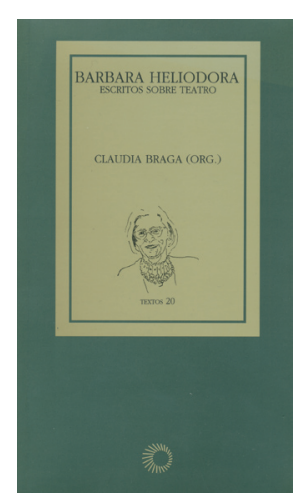

Barbara Heliodora: Escritos sobre Teatro, organização de Claudia Braga, São Paulo, Perspectiva, 2007, 950p.

\section{ALBERTO GUZIK} é crítico de teatro, dramaturgo e autor de, entre outros, $0 \mathrm{~s}$ Satyros: Um Palco Virtual (Imprensa Oficial). 
assim acessível a todos. A crítica tem um site oficial, http://www. barbaraheliodora. com, organizado por sua filha, a atriz $\mathrm{Pa}$ trícia Bueno. Seria esse o lugar ideal para receber todo o volume de trabalho produzido pela prolífica e incansável analista, valentemente processado pela equipe do Geteb. No site oficial da crítica, é possível encontrar algumas dezenas de comentários recentes, escritos já no séculoXXI. Aúltima crítica a ser postada no site data de abril de 2007. Não caberia acrescentar a esses textos todos os demais coletados?

Barbara Heliodora nasceu no Rio de Janeiro, no dia 23 de agosto de 1923, filha de Marcos Claudio Philippe Carneiro de Mendonça e Anna Amélia de Queiroz Carneiro de Mendonça. Da mãe escritora e poeta herdou o gosto pela literatura, pelo teatro, e a paixão por Shakespeare, cuja primeira obra completa ganhou de Anna Amélia, aos 12 anos. Do pai jogador de futebole engenheiro capturou a paixão pela pesquisa e pelo esporte. Além de crítica e professora, Barbara Heliodora foi eventualmente atriz, dirigiu alguns espetáculos e traduziu dezenas de textos teatrais. É autora de obras que se tornaram referência para os estudiosos do teatro, entre elas Falando sobre Shakespeare, Reflexões Shakespearianas e Martins Pena: Uma Introdução. Contam-se às dezenas seus artigos para revistas especializadas. A publicação de sua obra completa decerto exigiria mais alguns volumes tão maciços e encorpados quanto os seus Escritos sobre Teatro.

Embora o primeiro texto incluído nos Escritos, "Um Estudo sobre Chaucer", seja datado de 1944, é a partir de 1957 que Barbara Heliodora torna-se crítica de teatro profissional de fato. Nesse ano, indicada pelo dramaturgo Silveira Sampaio a Carlos Lacerda, passa a escrever regularmente na Tribuna da Imprensa, jornal dirigido pelo político carioca. Lá permanece por quatro meses. Logo foi colaborar com o Suplemento Dominical do Jornal do Brasil, onde ficou até 1964. Isso não significou seu afastamento da imprensa, pois voltaria a aparecer como colaboradora do Caderno B daquele periódico nos anos seguintes. Ao folhear os Escritos, o primeiro espanto deriva da quantidade de assuntos que a autora domina. Mesmo os que vêem com reservas sua estética, terão de concordar que ela escreve com autoridade. A multiplicidade de questões por que passam os Escritos é impressionante. Vai-se da política cultural à organização econômica da atividade teatral, passando por todos os aspectos teóricos e práticos dessa arte.

Um aspecto notável de seu trabalho é a linguagem equilibrada, clássica, que emprega em seus textos. Sempre temperada, conforme o caso, de ironia, fúria, indignação, sarcasmo, humor. Tudo em doses comedidas, como convém a quem deseja encontrar um equilíbrio adequado à função espinhosa que é o exercício da crítica, trabalho que requer coragem e responsabilidade. Essa busca de um tom clássico leva a escritora, em seus começos, a adotar um curioso procedimento, que certamente não seria emulado por uma escritora ou crítica que começasse carreira agora. Barbara Heliodora adota não apenas o plural majestático, como o faz no masculino. Mais de uma vez a autora declara que "estamos convencidos" disso ou daquilo. Hoje certamente se estranharia a adoção do uso do masculino para uma construção verbal que se refere a uma ação ou opinião da autora dos textos.

Por seu lado, a adoção do plural majestático é mais compreensível. Era um recurso corrente na primeira metade do século XX, adotado por todos os intelectuais que se lançavam a escrever nos órgãos de imprensa. Lembro-me de Sábato Magaldi explicando, em suas aulas de crítica na ECA-USP (nas priscas eras da escola, enquanto eu ainda trabalhava lá e tive a honra de ser, por alguns anos, seu assistente), que o plural majestático nada mais era que um “eu envergonhado". Ele dizia que o "nós" diluía o "eu”, tornava-o menos prepotente. $\mathrm{O}$ "eu" no jornalismo apenas se tornaria admissível depois da década de 50, com as conquistas do new journalism. Foi quando se reconheceu que o repórter e o colunista não eram entidades imateriais que se limitavam a reportar coisas vistas ou pensadas, 
mas seres humanos que reagiam como tais. E o "eu" seria finalmente consagrado e admitido mesmo pela chamada "grande imprensa" a partir da década de 60, depois do advento da imprensa alternativa, cujo maior exemplo brasileiro foi o Pasquim. Desde então uma maior informalidade na redação de textos destinados aos cadernos de cultura deixou de ser sinônimo de inaceitável leviandade.

Barbara Heliodora tem uma firme convicção sobre o papel do crítico. No texto datado de março de 1960, "Por que Somos Críticos?", escreve:

“Se o crítico é exigente, se tenta sempre reconduzir o teatro à sua verdadeira natureza de arte dramática, isso é exatamente a tarefa que lhe compete dentro de sua profissão. Um crítico não pode dizer de determinada atuação fraca que ela está ótima, porque nisso está sendo desonesto em dois sentidos: ilude o ator, que não terá de quem ouvir o fato de que é necessário que melhore sua qualidade de trabalho, e engana o possível espectador que porventura se queira orientar pela opinião do crítico. A função do crítico, parece-nos, não é a de agradar a gregos e troianos, assim como também não é a de atacar a tudo e a todos pelo simples prazer de destruir o trabalho alheio: sua função é árdua, justamente porque cumpre objetivar ao máximo sua avaliação do trabalho em questão, sem nenhuma prevenção ou favoritismo (ideal jamais integralmente alcançado, sem dúvida)” (p. 179).

E prossegue ela no mesmo texto:

"Como se forma um crítico? Qual a sua preparação profissional sine qua non? Que saibamos, é impossível encontrar resposta para essas duas perguntas, e acreditamos ser apenas possível dizer que não há nenhum tipo de estudo que forme, só ele, um crítico, mas que também não pode haver crítico sem estudo. O crítico terá, sem dúvida, que conhecer o passado e o presente do drama e do teatro, terá que ter uma grande experiência de espectador, terá que conhecer estudos feitos a respeito por muitos dos que se especializaram no assunto. Mas o crítico terá de contribuir com muito de seu, e toda sua formação estética será a dominante da linha mestra de seu trabalho: esta, ninguém lhe dará com régua de cálculo para saber dizer - aproximadamente - se um texto é bom ou ruim, o que há de bom num texto ruim ou o que há de ruim num texto bom. Falamos, é claro, do crítico jornalístico, pois o crítico que transcende sua época e sua circunstância é uma ave tão rara que não nos ocuparemos dela aqui” (pp. 179-80).

Para a ensaísta, a obrigação fundamental do crítico não é "se querer tornar agradável a este ou aquele, encobrindo defeitos sob um véu de elogios tangenciais, encorajando dessa forma a repetição do erro, bem como não é lícito que se exagerem os defeitos nem que se falte com o realce do mérito". Pouco adiante, acrescenta:

“O crítico fatalmente terá que evoluir constantemente, pois, a cada novo espetáculo, a cada novo texto, terá enriquecido sua experiência estética pessoal. Justamente aqui reside um de nossos maiores problemas teatrais, pois, até tão pouco tempo, o nosso teatro estava tão completamente reduzido a uma subforma digestiva de mero divertimento, que pesa sobre a presente geração a reconquista da dignidade da posição de arte maior para o mesmo."

\section{E conclui:}

“[...] porque ama o teatro, o crítico se torna crítico, mas há de amá-lo sem pieguices extremas, há de amá-lo com exigência, com a observação severa dos critérios estéticos definidos, pois só assim o crítico poderá fazer aquilo que tem por obrigação acima de todas as coisas: servir ao teatro no sentido de seu aprimoramento artístico consciente no sentido de sua existência viva dentro da realidade de uma época" (pp. 182-3).

Escritas há quase cinqüenta anos, essas palavras ainda refletem uma plataforma criteriosa e admirável. Pena que possa ser aplicada a bem poucos dos críticos que 
militam hoje na imprensa. Aliás, um dos aspectos sobre os quais Escritos sobre Teatro faz refletir é justamente o do empobrecimento da crítica teatral jornalística. Barbara Heliodora foi contemporânea de uma geração que incluiu Paulo Francis, Decio de Almeida Prado, Sábato Magaldi, Yan Michalski, Anatol Rosenfeld, Alberto D'Aversa, e muitos outros, um punhado de nomes brilhantes que ajudaram a fazer com que tanto o teatro brasileiro quanto a crítica teatral brasileira saíssem do berço esplêndido em que dormiam e acordassem para a vida, para as realidades de um tempo que exigia novos posicionamentos estéticos, éticos e políticos dos artistas.

Os princípios expostos acima, necessários ao exercício da crítica, são assumidos pessoalmente por Barbara Heliodora, que insiste no artigo corresponderem apenas ao seu ponto de vista. Mas eles, de certa forma, eram partilhados, com uma ou outra variação em aspectos secundários, por todos os seus colegas de geração. Na verdade, são princípios que regem a atividade como um todo, tanto na questão da estética quanto da ética, e que ainda agora permanecem vigentes.

De todos os críticos em atividade no Brasil, Barbara Heliodora é sem dúvida a mais longeva no ofício. Nos anos 40, participou dos grupos amadores que levaram à definitiva modernização do teatro, que até então patinava entre a comédia de costumes e o teatro de revista. Em 1948 ela atuou na histórica montagem do Hamlet do Teatro do Estudante, dirigida por Paschoal Carlos Magno. Barbara foi a Gertrudes do Hamlet de Sérgio Cardoso, que saiu consagrado dessa produção. Ela gosta de contar que, quando grávida de sua filha mais nova, deixou a produção, foi substituída por Cacilda Becker. De lá para cá, Barbara Heliodora testemunhou todas as fases do teatro brasileiro. Deixou de militar na crítica somente em um tempo de sua vida, entre 1970 e 1985 , quando se dedicou ao magistério e à carreira universitária, defendendo doutorado sobre aspectos da dramaturgia shakespeariana na Escola de Comunicações e Artes da USP e passando a dirigir o departamento de teatro da UniRio. A partir de 1986, aposentada, retomou o exercício da crítica, primeiro nas páginas da hoje extinta revista Visão e depois em $O$ Globo, onde permanece até a presente data.

À maneira de seus colegas de geração e de alguns críticos uma ou duas décadas mais jovens e que ainda militam na crítica jornalística, Barbara Heliodora aplica uma espécie de "receita" aos espetáculos que examina. Em que consiste? Ela parte de uma leitura do texto encenado, e aplica essa leitura à montagem. Se os parâmetros se ajustam e o espetáculo se encaixa no metro por ela empregado, a produção é considerada adequada. Caso contrário, será tida como inadequada. É interessante examinar como isso se processa na prática. Tome-se, à maneira de exemplo, o comentário de Barbara Heliodora à montagem de Jornada de um Longo dia para Dentro da Noite, de Eugene O'Neill, produzida pelo Teatro Cacilda Becker em 1958.

A autora inicia seu texto elogiando a iniciativa do TCB, seu mérito ao montar um texto tão complexo. Mas a seguir acrescenta:

"É por sentirmos patente a seriedade das intenções do Teatro Cacilda Becker que sentimos um certo pudor de fazer à sua produção da Jornada as seriíssimas restrições que fazemos, mas que nos parecem, por outro lado, inevitáveis, porque ela apresenta um dos mais traiçoeiros perigos da realização teatral: o erro crítico do diretor na interpretação do texto, que leva todo um grupo a um esforço numa direção errada. A grande falha da Jornada de um Longo Dia para Dentro da Noite está num desconhecimento absoluto do diretor do ambiente americano. Esse desconhecimento é manifesto no ambiente físico, psicológico e emocional da peça de O'Neill, traindo, portanto, o autor, essencialmente americano em quase tudo o que escreve, e certamente nesta obra autobiográfica" (p. 386).

Toda a sequiência do texto é elaborada no sentido de demonstrar que Ziembinski, equivocado em sua visão da obra-prima de 
Eugene O'Neill, provocou o descarrilamento da montagem. Mas não só ao diretor é creditado o erro:

“As falhas ambientais são, na realidade, de vários tipos, e acreditamos ser mais fácil situá-las de início, exteriormente, isto é, no cenário, de autoria do Sr. Gianni Ratto, que, nos parece, não conhece, ou pelo menos preferiu desconhecer, para esse trabalho, a arquitetura típica da Nova Inglaterra. Não há, na sala que vemos no palco do Dulcina, nada que nos fale nem remotamente do ambiente americano" (p. 387).

Quanto à direção, segundo a autora,

“Uma obra dramática é uma visão de um autor e, fatalmente, qualquer realização teatral dessa obra deve buscar interpretar o mais fielmente possível essa visão. Muito embora acreditemos que talvez o Sr. Ziembinski julgasse uma tal validez no texto de O’Neill que tenha julgado que o aspecto americano da obra não fosse primordial, estamos convencidos de que é justamente aí que reside a causa da incapacidade da realização teatral agora apresentada de ser considerada uma interpretação legítima da obra de O'Neill. O tipo de linguagem usado por O'Neill no original de Long's Day Journey Into Night é não só autêntico como linguagem diária de uma família - inteligente, intelectual e teatral, mas uma família -, porém, além disso, ele traz em si um determinado tipo de clima que não foi encontrado na produção brasileira da peça. Faltou à linha dada pelo Sr. Ziembinski a contenção que era absolutamente indispensável ao ambiente, para que nele pudéssemos sentir a angústia, a solidão individual de cada um, quebrada, de raro em raro, por desesperados momentos de auto-revelação que correspondem a tentativas de pedido de socorro que cada um daqueles quatro seres torturados faz aos outros três, por saber que por mais que se escondam no silêncio, no pudor, na personalidade falsa, a verdade de cada um é conhecida pelos outros, e que a mentira de todos os dias não consegue de todo encobrir a insegurança, a falta de confiança, a tortura e, acima de tudo, a verdade de que todos tentam ostensivamente fugir" (p. 388).

O que chama a atenção do leitor desse texto hojeé a certeza com que os argumentos são esgrimidos. Sobre a interpretação de Cacilda Becker, por exemplo, o cotejoé feito entre o que é proposto nas rubricas do texto original e aquilo que é feito no palco:

“[...] a rubrica de O'Neill fala de uma crescente ausência de Mary do ambiente da vida real, e dessa mesma e progressiva ausência fala constantemente o texto. Não encontramos justificativa, portanto, para o que nos pareceu mais uma crescente irritação com o meio ambiente, já que esse se torna, para Mary, cada vez mais irreal, já

\section{Ilustração de Glauco \\ Rodrigues}

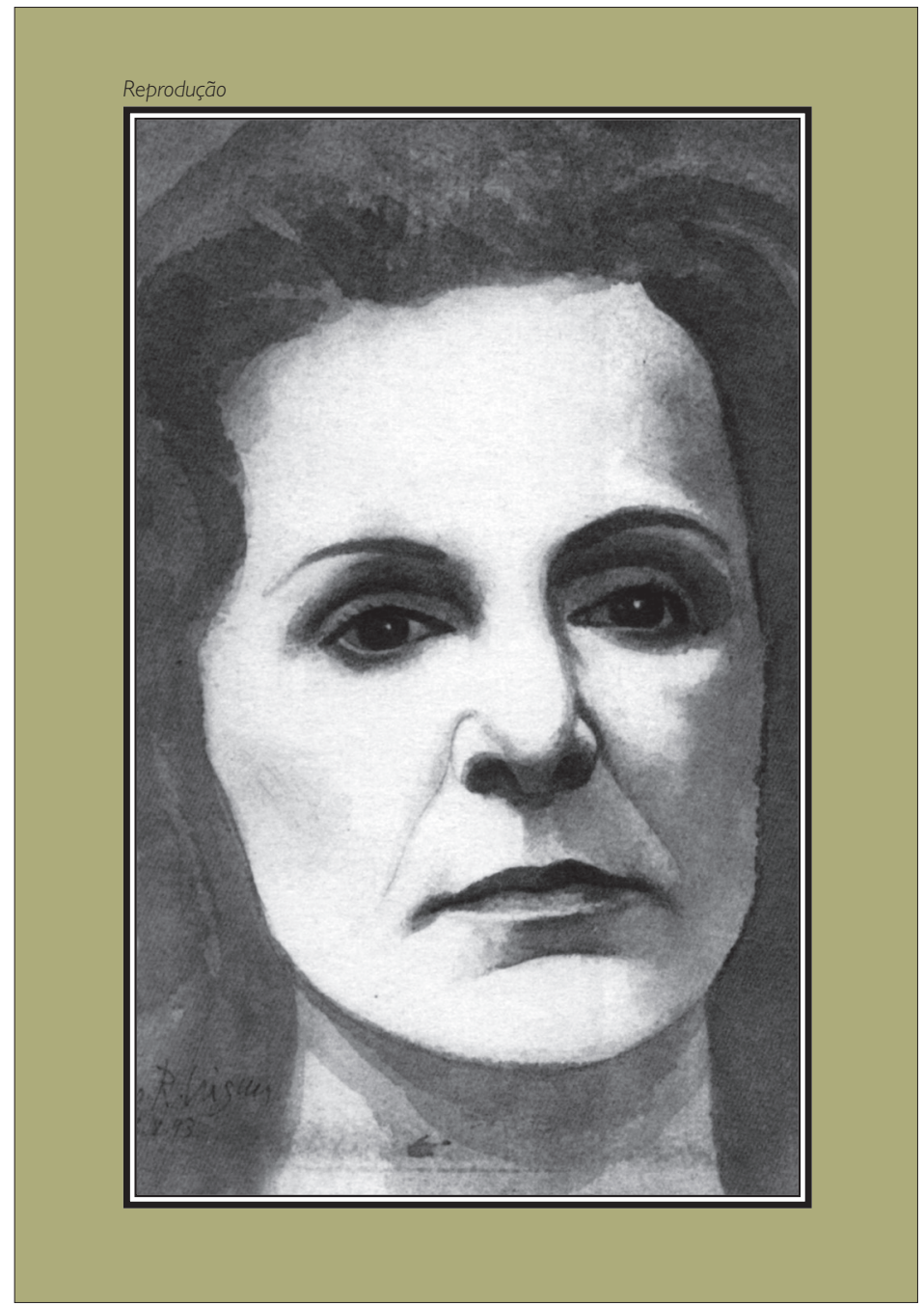


que cada vez mais ela vive num sonho de um passado idealizado. [...] Da maneira que foi feito o trabalho de Cacilda Becker no papel de Mary, o resultado do uso da morfina foi retratado em termos de crescente excitação e irritação, com uma impaciência e uma agitação por demais compostas, de maneira que seus raros momentos de ausência ficaram deslocados" (p. 390).

A argumentação de Barbara Heliodora evidencia a estrutura hierárquica sobre a qual sua crítica repousa. Em primeiro lugar, antes de qualquer outra coisa, vem o dramaturgo, o portador da palavra, da idéia, da poesia. Seu texto, a razão de ser do espetáculo, deve ser corretamente lido pelo diretor, que a partir dessa visão construirá seu espetáculo. E o crítico, o leitor ideal do texto original, saberá cobrar da montagem a fidelidade ou a infidelidade à palavra do dramaturgo. Em tempos mais recentes essa visão da crítica foi temperada por muitas outras variantes. Os críticos assumiram a primeira pessoa, tornaram-se menos solenes e passaram a dar mais importância ao conjunto do trabalho teatral, vindoeventualmente a acatar interferências da direção no texto, quando justificadas pela estética da encenação. As análises de Barbara Heliodora pertenciam e pertencem até hoje, como se pode ver pelas críticas postadas em seu site, a diversa escola, na qual não esteve sozinha. De uma maneira ou de outra, todos os críticos listados acima, companheiros de estrada de Barbara Heliodora, partilharam daquela outra visão da crítica, na qual o autor do comentário assumia o risco de expor um ponto de vista absoluto, e não relativo, sobre uma obra de arte.

É preciso ressaltar que as aspirações da autora para o teatro brasileiro são sempre as mais elevadas, o que explica em grande parte a severidade do metro que aplica às obras que examina. Revela-se exímia analista de estilos. Fica patente a intimidade com que disserta sobre o teatro de George Bernard Shaw. De Shakespeare, então, nem se fala. Seus comentários são consistentes, repletos de informações. A visão didática da crítica é absoluta, e não relativa, no trabalho de Barbara Heliodora. Para ela, o crítico é o professor, o educador, aquele que diz o que deve ser dito, não para magoar, mas para educar, para fazer crescer o artista. Há um programa estético em seus textos, indiscutivelmente. A tarefa construtora de sua geração, e da geração de artistas que ela acompanhou, foi efetivamente levada a sério, como se pode observar nesse livroem um conjunto de tex tos que, mesmo quando dogmáticos, cobram excelência do teatro que examinam.

Barbara Heliodora mostra em vários textos como esteve sempre antenada com a realidade teatral do mundo. Em artigo de 1959, ela define Bertolt Brecht como “inimitável”. E o considera uma "estranha figura que domina, tranquiila, o intranqüilo panorama do teatro do século 20" (p. 146). Barbara admite que o papel do crítico não é analisar a ideologia do dramaturgo, mas sua obra. E observa:

“A verdade finalé que Brecht não sobrevive no palco por suas teorias, e que tampouco seu trabalho foi o resultado de uma preocupação teórica: a teoria foi evolvida da experiência e o que mais tarde parecia inútil ao autor era tranqüilamente descartado. $\mathrm{O}$ que vive é seu talento e sua maneira personalíssima: em Mãe Coragem, O Círculo de Giz. Caucasiano, A Alma Boa de Se-Tsuan, assim como na Ópera de Três Vinténs, muito mais antiga, há um sentido dramático básico que se manifesta pelos meios que Brecht escolheu com a sua expressão especial. Acreditamos, realmente, que seja inimitável"' (pp. 148-9).

Alguém como ela, com princípios estéticos tão elevados, pode surpreender o leitor ao render-se com prazer ao humor do besteirol, gênero de teatro carioca que teve sua vez em fins dos anos 80 e no começo dos 90. Em artigo de 1988, que tem por tema $A s$ Sereias da Zona Sul, espetáculo composto por quatro peças curtas de Miguel Falabella e Vicente Pereira, ela assinala algumas características do gênero: “Como todas as boas peças de besteirol, as duas de Falabella e a 
última de Vicente Pereira são extremamente tópicas, com universos ricos de referências ao aqui e agora do viver brasileiro/carioca, à intimidade do teatro e da televisão, ao mais terrível colunismo social". E indica o modo pelo qual funciona a atuação dos intérpretes do besteirol: “Texto e ação estão em perfeita sintonia e Jacqueline Laurence (a diretora) demonstra grande sabedoria ao controlar com rédea solta, e apenas na medida do realmente indispensável, o histrionismo de [Miguel] Falabella e [Guilherme] Karam, que maior disciplina só poderia prejudicar”. E acrescenta uma observação sobre a estética do espetáculo: “A cenografia de Guilherme Karam é tão atraente quanto funcional, refletindo o quanto, por trás de sua aparente loucura, o besteirol tem de requinte e gosto"' (p. 803).

A escritora esteve sempre atenta a todas as formas de teatro, comédias e tragédias, experiências eruditas e populares. Sobre Brincante, que viu no Festival de Teatro de Curitiba em 1992, escreveu:

“Ao que parece, é em Recife que se encontra achave do segredo: o 'Autoda Compadecida' foi o primeiro exemplo de sucesso absoluto na mistura do erudito com o popular e agora, graças talvez a suas ligações com Suassuna via Armorial, Antonio Nóbrega apresenta, com seu espetáculo 'Brincante', um momento luminoso no FTC. Ator, dançarino, músico, instrumentista, Nóbrega mescla todas essas aptidões e capacidades com a mesma simplicidade espontânea e encantadora com que realiza seu espetáculo. [...] é necessário fazer um esforço supremo para não se ficar totalmente envolvido por esse malicioso e divertido encantador de serpentes, e preservar algum distanciamento crítico que ainda permita que se tenha consciência do vasto universo de erudição apresentado com a aparência do mais singelo e autêntico lendário popular; nada mais evocativo do mundo maravilhoso do circo do interior do que o pomposo vocabulário do apresentador, que é quase correto, e, nele, como nas evocações de-pelo menos-Plauto, Shakespearee Brecht, o clima da literatura de cordel unifica o todo sem que fique aparecendo um único desnível, uma única costura” (p. 838).

Uma das características importantes da crítica de Barbara Heliodora está no fato de ser, além de boa analista de textos

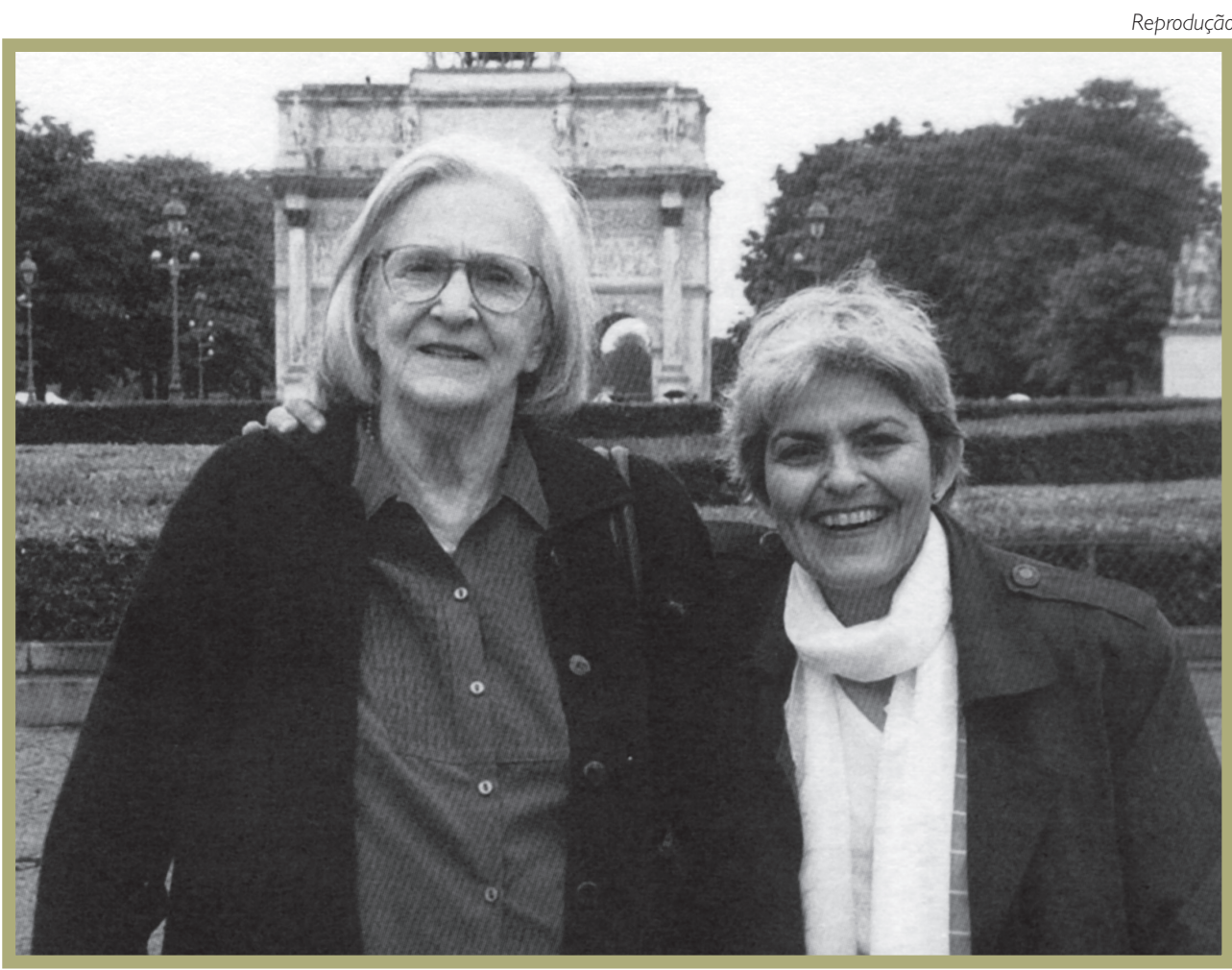

Barbara Heliodora com Claudia Braga em Paris 
dramáticos, uma ótima observadora do trabalho dos atores. Eis o que escreve em 1994, no 25 aniversário da morte de uma atriz cuja carreira ela acompanhou muito de perto:

"Passados tantos anos de sua morte, Cacilda Becker continua a ser uma figura iluminada, uma presença forte e encantadora. Ainda há bem pouco tempo a TVE retransmitiu Casa de Bonecas de Ibsen, gravada há décadas na TV Cultura de São Paulo; era tudo de uma outra época, precária e iniciante nos mistérios do teleteatro: cenários pintados horríveis, interpretações quase que uniformemente exageradas, e claramente datando de um outro tempo; e no meio daquilo tudo, de todos os tropeços e enganos, Cacilda brilhava com uma interpretação moderna, limpa, que poderia ser inserida em alguma nova versão em que tudo o mais tivesse sido substituído. Não há qualquer explicação para isso senão aquela coisa intangível chamada talento: pequena, magérrima, falando com o que ela mesmo dizia: 'essa vozinha que Deus me deu', quando Cacilda Becker entrava em cena, mesmo que fosse na última fila e vestida igual a vinte outras pessoas, a sua presença individual era imediatamente notada" (p. 904).

Destaca-se no conjunto dos trabalhos inseridos no livro uma seqüência de textos escritos nos anos 60-70, nos quais, com coragem e destemor, Barbara Heliodora investe contra a censura imposta ao teatro e ao país durante o regime militar. Em março de 1968, ano em que se acirram os confrontos entre opositores do regime e os militares no poder, Barbara Heliodora escreve um longo texto no Caderno B do Jornal do Brasil tratando especificamente de uma entrevista sobre a censura dada pelo coronel Florimar Campelo, diretor-geral do Departamento de Polícia Federal, ao qual estava afeta a atividade censória. Registra ela, sobre a centralização da Censura Federal em Brasília:

"Argumenta o coronel que a censura foi centralizada em Brasília porque houve na Guanabara e em São Paulo influências sobre as delegacias regionais. A essa altura realmente ficamos perturbados, pois como poderemos ter um julgamento criterioso daquilo que lhe é submetido se o próprio coronel Campelo declara que ela é integrada por pessoas influenciáveis? Como poderemos então nos sentir seguros de que será possível ao coronel zelar pela integridade moral da maioria do povo se, segundo suas

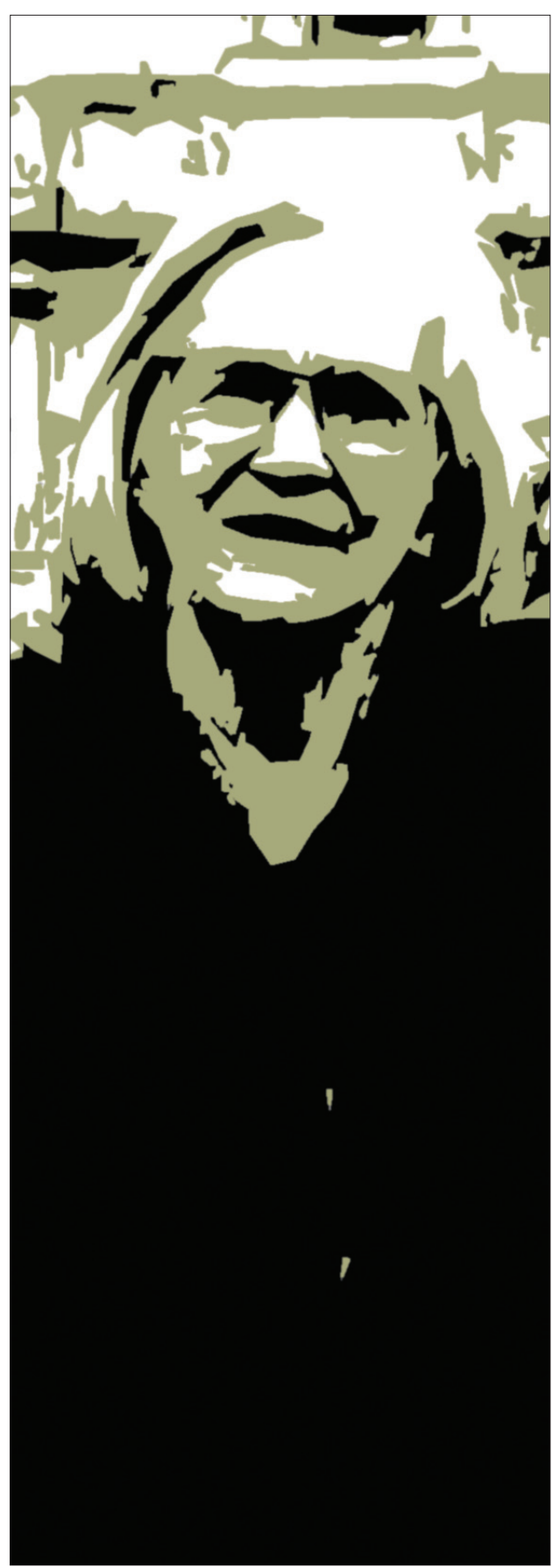


próprias declarações, não lhe tem sido possível garantir a integridade dos membros da própria Censura?"' (p. 726).

E o artigo ganha uma ironia arrasadora quando ela se refere ao fato de o coronel Campelo ter citado Shakespeare em sua entrevista, afirmando que o dramaturgo nunca havia usado palavrões e nem por isso deixava de ser o maior autor teatral do mundo. A autora rebate observando que a declaração do coronel deveria ser retificada para "Shakespeare usou muitos palavrões e nem por isso deixa de ser o maior dramaturgo do mundo". A partir daí, com grande dose de ironia, beirando quase o sarcasmo, oferece-se para emprestar ao coronel obras em que ele poderá retificar suas opiniões equivocadas sobre a pureza da linguagem de Shakespeare.

"Compreendemos muito bem o lapso do coronel Campelo. À primeira vista, seria fácil atribuir sua declaração a um total desconhecimento da obra shakespeariana. Porém isso seria injusto, pois não se pode sequer admitir que o responsável pela censura se arriscasse a fazer uma declaração tão definitiva a respeito de um assunto que desconhecesse totalmente. Preferimos acreditar que, inadvertidamente, o coronel Campelo fez, ele próprio, a maior defesa do ponto de vista que nós temos defendido aqui e nas escadarias do Municipal, junto com toda a vasta classe de artistas de todos os setores. Ao pensar em Shakespeare e no enorme prazer que sem dúvida tem tido em todos os seus contatos com a obra do maior dramaturgo do mundo, o coronel Campelo não se lembrou dos palavrões, porque numa obra de arte o que nos fica na memória não são os palavrões. A lembrança que fica de Shakespeare é a da inigualável riqueza do panorama humano apresentado."

\section{E Barbara Heliodora conclui:}

"[...] sabendo compreender as palavras do coronel, realmente vemos que ele está defendendo o nosso ponto de vista. Agora que ele mesmo tem a prova, por intermé- dio de suas próprias palavras, da verdade sobre a natureza da obra de arte, estamos convencidos de que é impossível que ele não concorde conosco que não é necessária a censura, que o teatro, como toda arte, tem que viver livre, porque sólivre ele é capaz de produzir um Shakespeare” (pp. 727-8).

Infelizmente os argumentos brilhantes da escritora nesse e em outros artigos seus nos quais atacou com valentia a censura e o arbítrio não tiveram a menor influência sobre a repressão. Ao contrário. Em dezembro de 1968 foi editado o A to Institucional no 5 , que liquidou de vez com as poucas liberdades de expressão que ainda restavam. O país todo entrou numa longa década de trevas culturais. E durante todo esse tempo o teatro teve em Barbara Heliodora uma aliada vigorosa e destemida, que defendeu sempre a democracia e a pluralidade de idéias.

Um aspecto da atividade teatral que $E s$ critos sobre Teatro aborda com constância está nos textos da seção “Teatro e Estado", em que Barbara Heliodora, além de alvejar a censura, analisa critérios de política cultural e de distribuição de verbas estatais. Aponta despropósitos, aplaude acertos, ataca escolhas que lhe parecem disparatadas. Está sempre atenta às relações da classe teatral com os mecanismos liberadores de verba dos órgãos públicos. É uma observadora vigilante que denuncia abusos e elogia atos conseqüientes. Sua posição é clara: sempre a favor da transparência, do bom uso do dinheiro público destinado ao teatro. E esses textos, datados de trinta anos atrás, nos fazem tomar consciência de como mudaram as políticas culturais no país ao longo desse tempo. Hoje, o financiamento público da cultura é uma história que pertence ao passado. O que temos são leis de incentivos, mecanismos perversos que penalizam companhias mais jovens e as experimentais, que não contam com nomes estelares. Os escritos de Barbara Heliodora nos fazem ver que em tempos não remotos havia outra atitude dos órgãos estatais no trato com a cultura. Mesmo que com distorções e desacertos, que Barbara Heliodora aponta em seus textos, o en- 
tendimento do preceito constitucional de que era dever do Estado apoiar a cultura se traduzia em fatos concretos, não em leis de incentivos.

O estilo da autora, mesmo no início, mais engessado pela formalidade, prima pela clareza, pela legibilidade. Não é hermética nem enfadonha sua escrita. Freqüentemente usa o humor e a ironia como armas de análise. Seu livro nos leva por uma viagem no tempo que abarca um longo período, decisivo, na história do teatro brasileiro. Seu testemunho dá o que pensar. E o livro, involuntariamente, depõe sobre o encolhimento do espaço da crítica na imprensa, ao longo das últimas décadas. Basta comparar o tamanho das críticas escritas pela autora na década de 50 com seus textos produzidos a partir dos anos 80 para perceber que a retração dos centímetros concedidos aos comentaristas teatrais é flagrante.

Uma conseqüência do trabalho de Barbara Heliodora é tangencialmente abordada pela organizadora Claudia Braga em seu prefácio, quando afirma, em uma linha na p. 16 do livro, que "Falar de Barbara Heliodora é falar de polêmica". Sem dúvida está certa. Não foram poucas as controvérsias e polêmicas suscitadas pela obra dessa estudiosa do teatro. No entanto, suas posições mais controvertidas estão disseminadas aqui e ali, em artigos ao longo do livro, sem que o leitor tenha a possibilidade de perceber no conjunto as posturas defendidas pela escritora. E Claudia Braga limita sua referência à polêmica a essa linha da apresentação. Sobre isso mais não se fala. Um livro desse porte deveria oferecer ao leitor um desenho mais nítido dessas brigas compradas pela aguerrida comentarista teatral. Percebe-se aí a falha da organização. Além da apresentação de Braga e do material produzido por Barbara Heliodora, o volume teria de conter um estudo aprofundado, que oferecesse também ao leitor informações sobre a posição dela dentro da cena brasileira. O livro carece de um texto que fizesse a "crítica da crítica", de modo a levar o leitor a abarcar um horizonte mais amplo e diversificado. A introdução de Claudia Braga traça uma espécie de "história oficial". E o volume ficou carente de um ensaio que nos trouxesse outros lados, outras facetas de uma trajetória ímpar.

Esse, porém, é um problema da organização do livro, e não atinge o material nele contido. A crítica de Barbara Heliodora reunida em Escritos sobre Teatro revela um ato de resistência e de lucidez. Que novas gerações de críticos não se reconheçam nela, como ocorre com os inteligentes e antenados garotos que fazem a revista Bacante em São Paulo (www.bacante. com.br), é natural e desejável. Cabe a cada geração de críticos forjar seus próprios itinerários estéticos e fazer suas apostas. As de Barbara Heliodora sempre apontaram para a busca de um teatro de qualidade, um teatro digno, intelectualmente ambicioso, exercido com toda habilidade que essa arte requer. Eu seguramente consigo me identificar muito facilmente com tal ideário. E ao concluir a leitura do grosso volume senti-me certo do montante da contribuição de Barbara Heliodora ao teatro brasileiro, em que pesem todas as polêmicas e desavenças suscitadas por seus escritos. Sua crítica está centrada em uma sólida observação posta a serviço de uma perspicácia abrangente e exigente.

Não sei se ela é "a maior crítica do teatro brasileiro" como afirmam alguns, entre eles Claudia Braga, pois não conheço nenhum "criticômetro" que permita medir o tamanho de Barbara em relação ao de Yan, de Decio ou de Sábato, por exemplo. É a mais longeva, sem dúvida, a que mais tempo dedicou ao seu mister. E a ética com que se pautou em uma bem longa carreira, assim como a solidez de sua produção, sempre estiveram e ainda estão acima de qualquer suspeita. Estudantes de teatro, historiadores, atores, diretores e dramaturgos, além dos críticos e também dos formuladores de políticas culturais que envolvem o teatro, terão muito a lucrar com a leitura de Barbara Heliodora: Escritos sobre Teatro. O volume provocará muitas conversas, discussões, e decerto suscitará polêmicas. Estou seguro de que a autora não deseja outra coisa. Ela sabe perfeitamente que do confronto de opiniões nasce o movimento e o movimento gera a energia que faz a arte avançar. 